\section{Can IL-1 be used as a target for osteoarthritis?}

We read with deep interest the article by Kloppenburg et al, ${ }^{1}$ which was aimed at assessing the efficacy, safety, pharmacokinetics and pharmacodynamics of anti-interleukin (IL)- $1 \alpha / \beta$ dual variable domain immunoglobulin lutikizumab (ABT-981) in erosive hand osteoarthritis (HOA). The results indicated that administration of $200 \mathrm{mg}$ lutikizumab subcutaneously every 2 weeks for 24 weeks did not improve pain or imaging outcomes in erosive HOA compared with a placebo. This conclusion might be disappointing for doctors and even patients who desire a wider choice in drugs.

In this study, the authors administered lutikizumab to neutralise the expression of IL- $1 \alpha$ and IL- $1 \beta$; however, to the best of our knowledge, until recently, the source of IL-1 was unclear and whether active IL-1b is produced in osteoarthritic cartilage remains highly controversial, ${ }^{2}$ although it is well known that IL-1 is one of the two prototypical proinflammatory cytokines that participate in the pathogenesis of degradation of extracellular matrix and joint inflammation in OA. ${ }^{3}$ IL-1 was first identified in the late 1970s as an inflammatory mediator capable of tissue damage and was widely added to cultured chondrocytes or synovial cells to mimic the osteoarthritic condition in vitro. ${ }^{4}$ Previous studies confirmed that in cartilaginous specimens, IL- $1 \beta$, but not IL-1 $\alpha$, was detected as diffuse staining of the extracellular matrix, especially surrounding superficial zone chondrocytes. ${ }^{5}$ However, not every osteoarthritic cartilage could express IL- $1 \alpha$ and IL-1 $\beta$; the mild-to-moderate osteoarthritic cartilage had a higher proportion of IL- $1 \alpha$ and IL-1 $\beta$ positive cells than more severely degenerated cartilage. Moreover, IL- $1 \alpha$ and IL-1 $\beta$ expression in patients with severely degenerated cartilage was even lower than that in asymptomatic people. ${ }^{5}$ The production of IL-1 requires caspase 1 to activate its precursor, pro-IL-1 $\beta$. Caspase 1 itself must be converted from procaspase 1 to active caspase 1 via the molecular scaffold, 'inflammasome'; however, the inflammasome constituents, the nucleotide-binding domain leucine-rich repeats family protein 3 , apoptotic speck-containing protein and caspase 1 , were not strongly expressed in osteoarthritic cartilage; therefore, IL- $1 \beta$ may not be produced by the cartilage. ${ }^{56}$ Therefore, in erosive HOA, the expression levels of IL- $1 \alpha$ and IL- $1 \beta$ might not be originally elevated or changed with the progression of OA; in this study, IL- $1 \alpha$ and IL- $1 \beta$ serum levels were measured at baseline and weeks 2 and 4 , and it was difficult to determine the changes in IL- $1 \alpha$ and IL- $1 \beta$ serum levels afterwards.

According to the recommendations of Osteoarthritis Research Society International regarding the design and conduct of clinical trials for $\mathrm{HOA}^{7}$ it is best to evaluate parameters, including pain, physical function, patient global assessment, health-related quality of life, joint activity and hand strength in the clinical trials. To the best of our knowledge, the authors did not report the results of the patient global assessment, health-related quality of life, joint activity and hand strength in this paper. It is necessary to determine whether there was any difference in the improvement of hand symptoms after treatment with the drug when both hands of the patient were involved.
We respect the significant contributions of the authors, and look forward to the follow-up results of this study.

\section{Chao Cheng, ${ }^{1,2}$ Jian Tian, ${ }^{3}$ Fangjie Zhang ${ }^{4}{ }^{4}$}

${ }_{1}^{1}$ Department of Orthopaedics, Yiyang Central Hospital, Yiyang, China

${ }^{2}$ Clinical Medical Technology Demonstration Base for Minimally Invasive and Digita Orthopaedics in Hunan Province, Yiyang, China

${ }^{3}$ Department of Orthopaedics, Xiangya Hospital, Central South University, Changsha, China

${ }^{4}$ Department of Emergency Medicine, Xiangya Hospital, Central South University, Changsha, China

Correspondence to Dr Fangjie Zhang, Department of Emergency Medicine, Xiangya Hospital, Central South University, Changsha 410008, China; zhangfj11@163.com

Contributors CC: concept and writing; JT: concept; FZ: concept and revising.

Funding This work was supported by the Natural Science Foundation of China (grant number 81501923).

Competing interests None declared.

Patient consent for publication Not required.

Provenance and peer review Not commissioned; internally peer reviewed.

(c) Author(s) (or their employer(s)) 2020. No commercial re-use. See rights and permissions. Published by BMJ.

\section{A) Check for updates}

To cite Cheng C, Tian J, Zhang F. Ann Rheum Dis 2020;79:e88.

Received 9 April 2019

Revised 16 April 2019

Accepted 23 April 2019

Published Online First 30 April 2019

\section{S Linked}

http://dx.doi.org/10.1136/annrheumdis-2019-215612

Ann Rheum Dis 2020;79:e88. doi:10.1136/annrheumdis-2019-215513

ORCID iD

Fangjie Zhang http://orcid.org/0000-0002-7502-5830

\section{REFERENCES}

1 Kloppenburg M, Peterfy C, Haugen IK, et al. Phase IIA, placebo-controlled, randomised study of lutikizumab, an anti-interleukin- $1 \alpha$ and anti-interleukin-1 $\beta$ dual variable domain immunoglobulin, in patients with erosive hand osteoarthritis. Ann Rheum Dis 2019:78:413-20.

2 Bougault C, Gosset M, Houard X, et al. Stress-induced cartilage degradation does not depend on the NLRP3 inflammasome in human osteoarthritis and mouse models. Arthritis Rheum 2012;64:3972-81.

3 Goldring MB, Berenbaum F. The regulation of chondrocyte function by proinflammatory mediators: prostaglandins and nitric oxide. Clin Orthop Relat Res 2004;(427 Suppl):S37-46.

4 Goldring SR, Goldring MB. The role of cytokines in cartilage matrix degeneration in osteoarthritis. Clin Orthop Relat Res 2004;(427 Suppl):S27-36.

5 Towle CA, Hung HH, Bonassar LJ, et al. Detection of interleukin-1 in the cartilage of patients with osteoarthritis: a possible autocrine/paracrine role in pathogenesis. Osteoarthritis Cartilage 1997:5:293-300.

6 Liu-Bryan R, Terkeltaub R. Emerging regulators of the inflammatory process in osteoarthritis. Nat Rev Rheumatol 2015;11:35-44.

7 Kloppenburg M, Maheu E, Kraus VB, et al. OARSI clinical trials recommendations: design and conduct of clinical trials for hand osteoarthritis. Osteoarthritis Cartilage 2015;23:772-86 